\title{
Molybdenum dosage and application timing in sweet corn
}

\section{Dosis y épocas de aplicación de molibdeno en maíz dulce}
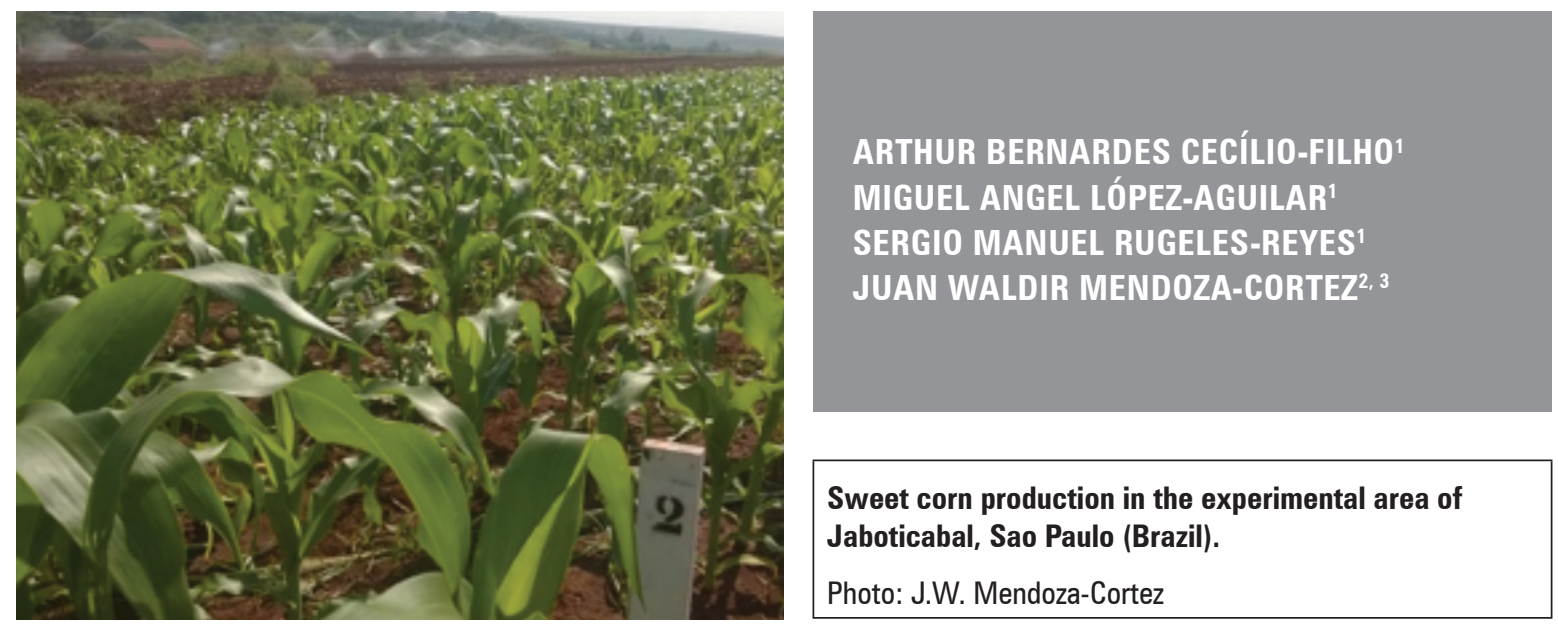

Sweet corn production in the experimental area of Jaboticabal, Sao Paulo (Brazil).

Photo: J.W. Mendoza-Cortez

\begin{abstract}
Nowadays, there is a greater offer of sweet corn hybrids with a high productive potential, shorter cycle and more intense metabolism than common corn, resulting in this crop being very demanding in terms of nutrients. The present study aimed to evaluate the effect of three levels of molybdenum (Mo) (150, 300 and 450 $\left.\mathrm{g} \mathrm{ha}^{-1}\right)$, via foliar spraying, with different application timing $\left(\mathrm{E}_{1}: 100 \%\right.$ at 15 days after emergence - DDE; $\mathrm{E}_{2}$ : $100 \%$ at $30 \mathrm{DDE} ; \mathrm{E}_{3}: 100 \%$ at $45 \mathrm{DDE} ; \mathrm{E}_{4}: 50 \%$ at 15 and $30 \mathrm{DDE}$, and $\mathrm{E}_{5}: 33.3 \%$ at 15,30 and $45 \mathrm{DDE}$ ) on the agronomic performance of sweet corn 'SVN 9298'. There was a significant effect from the interaction of the factors on the foliar concentration of Mo, obtaining the highest value with $450 \mathrm{~g} \mathrm{ha}^{-1}$ of Mo, applied at 45 $\mathrm{DDE}$, with an increase of $1.2 \%$ in the foliar content from that observed in the plants without a Mo application. Also, the foliar concentration of nitrogen $(\mathrm{N})$ was higher with the highest Mo level. The highest number of commercial ears $(49,583)$, total productivity of ears $\left(20,942 \mathrm{~kg} \mathrm{ha}^{-1}\right)$ and productivity of commercial ears $\left(13,211 \mathrm{~kg} \mathrm{ha}^{-1}\right)$ were obtained with estimated levels of 316,450 and $311 \mathrm{~g} \mathrm{ha}^{-1}$ of Mo, respectively. Likewise, the dose that maximized grain productivity $\left(5,055 \mathrm{~kg} \mathrm{ha}^{-1}\right)$, which is the most important component that defines the agronomic performance of sweet corn, was the estimated dose of $334 \mathrm{~g} \mathrm{ha}^{-1}$ of Mo.
\end{abstract}

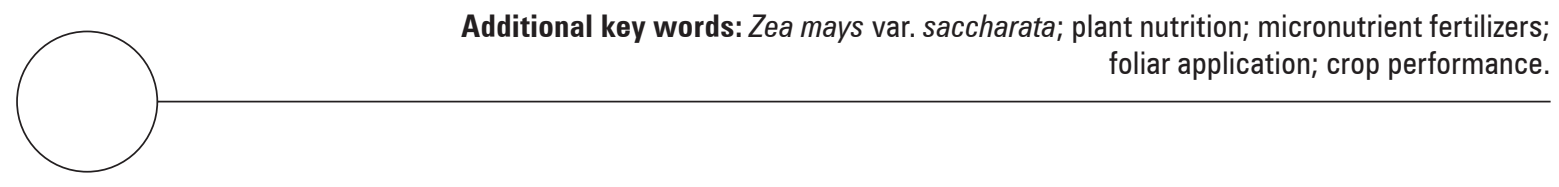

\footnotetext{
1 Universidade Estadual Paulista (UNESP), Faculty of Agricultural and Veterinary Sciences, Department of Plant Production, Jaboticabal (Brazil). ORCID Cecílio-Filho, A.B.: 0000-0002-6706-5496; ORCID López-Aguilar, M.A.: 0000-00031389-734X; ORCID Rugeles-Reyes, S.M.: 0000-0002-7464-3864

2 Universidad Nacional Agraria La Molina (UNALM), Faculty of Agronomy, La Molina, Lima (Peru). ORCID Mendoza-Cortez, J.W.: 0000-0002-2158-0943

3 Corresponding author. jmendoza@lamolina.edu.pe
} 


\section{RESUMEN}

Actualmente, debido a la mayor oferta de híbridos de maíz dulce con alto potencial productivo, ciclo más corto y un metabolismo más intenso que el maíz común, hacen que este cultivo sea muy exigente en nutrientes. En ese sentido, el presente trabajo tuvo como objetivo evaluar el efecto de tres dosis de molibdeno (Mo) (150, 300 y $\left.450 \mathrm{~g}_{\text {ha }}{ }^{-1}\right)$, vía foliar, en diferentes épocas de aplicación $\left(\mathrm{E}_{1}: 100 \%\right.$ a los 15 días después de la emergencia - DDE; $\mathrm{E}_{2}: 100 \%$ a los 30 DDE; $\mathrm{E}_{3}: 100 \%$ a los $45 \mathrm{DDE} ; \mathrm{E}_{4}: 50 \%$ a los 15 y $30 \mathrm{DDE}$, y $\mathrm{E}_{5}: 33,3 \%$ a los 15,30 y $45 \mathrm{DDE}$ ), sobre el desempeño agronómico del maíz dulce 'SVN 9298'. Se presentó interacción significativa de los factores sobre la concentración foliar de Mo, obteniéndose el mayor valor con $450 \mathrm{~g} \mathrm{ha}^{-1}$ de Mo aplicado a los $45 \mathrm{DDE}$, siendo equivalente al incremento de 1,2\% con relación al contenido foliar observado en las plantas sin aplicación de Mo. También, la concentración foliar del nitrógeno $(\mathrm{N})$ fue mayor con la dosis más alta de Mo utilizada. Los mejores resultados para el número de espigas comerciales (49.477), productividad total de espigas $\left(20.942 \mathrm{~kg} \mathrm{ha}^{-1}\right.$ ) y productividad de espigas comerciales (13.211 $\mathrm{kg} \mathrm{ha}^{-1}$ ) fueron obtenidos con las dosis estimadas de 316, 450 y $311 \mathrm{~g} \mathrm{ha}^{-1}$ de Mo, respectivamente. Asimismo, la dosis que maximizó la productividad de granos $\left(5.055 \mathrm{~kg} \mathrm{ha}^{-1}\right)$, que es el componente más importante que define el desempeño agronómico del maíz dulce, fue obtenida con la cantidad estimada de $334 \mathrm{~g}$ ha ${ }^{-1}$ de Mo.

Palabras clave adicionales: Zea mays var. saccharata; nutrición vegetal; fertilizantes de micronutrientes; aplicación foliar; desempeño de cultivos.

Received for publication: 29-04-2019 Accepted for publication: 31-07-2019

\section{INTRODUCTION}

In Brazil, sweet corn (Zea mays var. saccharata) is grown in approximately 30,000 ha, with $90 \%$ of that area located in the State of Goiás (Luz et al., 2014). In the State of São Paulo, sweet corn is in great demand in the industrial sector (because of the sweet taste of the grains and the effect of different mutant alleles that control the conversion of starch into sugar), especially for the manufacture of canned food (Mendoza-Cortez et al., 2016).

Mineral nutrition and crop fertilization are among the factors that influence high productivity. Although it is necessary in only small amounts $(0.1$ to $0.2 \mathrm{mg}$ $\mathrm{kg}^{-1}$ of dry matter) (Maynard and Hochmuth, 2007), $\mathrm{Mo}$ is a micronutrient of great importance because it is a nitrate reductase enzyme (Hamlin, 2007; Fageria, 2009), indispensable in the metabolism of $\mathrm{N}$ and, therefore, having an indirect effect on the growth and productivity of crops.

Most soils contain enough amounts of this micronutrient; however, its absorption is affected under conditions of low temperatures, high $\mathrm{N}$ fertility (Hamlin, 2007), high rainfall and, mainly, acidic soils, where it is strongly adsorbed at the surface of iron and aluminum oxides, becoming unavailable to plants (Fageria, 2009).
A deficiency of this micronutrient is more evident during the reproductive phase than in the vegetative phase (Hamlin, 2007). Mo-deficient corn plants are more likely to have premature sprouting of the grains, which is accentuated when there is a greater availability of $\mathrm{N}$ in the soil (Tanner, 1978). In addition, there is a reduction in the size of tassels, male flowers and anthers; there is anthesis suppression and delay, decrease in the activity of some enzymes and increase of others, which affect the viability of pollen during development (Agarwala et al., 1979). On the other hand, Mo toxicity in plants is rare, even when there is a high absorption rate of this micronutrient, especially under field conditions (Leite et al., 2007).

Methods to prevent Mo deficiencies include in-band or field-wide applications, foliar applications and seed treatment. According to Hamlin (2007), foliar applications are much more efficient than soil applications, especially in acidic soils or under dry weather conditions.

The small number of studies carried out on Mo applications, via foliar or associated with $\mathrm{N}$ applied to the soil, are for conventional corn and corn used for popcorn (Valentini et al., 2005; Teixeira, 2006; Araújo 
et al., 2010; Pereira, 2010; Santos et al., 2010; Santos et al., 2012; Gaspareto et al., 2014; Caioni, 2015). There is a shortage of current information on sweet corn under Brazilian conditions.

In this context, the objective of the present study was to evaluate the agronomic performance of sweet corn as a function of molybdenum dose, supplied via foliar applications, with different application timings.

\section{MATERIALS AND METHODS}

This experiment was conducted in the municipality of Jaboticabal, State of Sao Paulo, Brazil, between August and November of 2015.

The soil in the experimental area was classified as Latossolo Vermelho (EMBRAPA, 2006). Before the installation of the experiment, the soil was sampled at a depth of 0 to $20 \mathrm{~cm}$, and, according to the results of the chemical analysis, the soil had: $\mathrm{pH}$ of $5.7 ; 22$ $\mathrm{g} \mathrm{dm}^{-3}$ of organic matter; 40 and $11 \mathrm{mg} \mathrm{dm}^{-3}$ of $\mathrm{P}$ (resin) and S, respectively; 44; $14 ; 3.3$ and $30 \mathrm{mmol}_{c} \mathrm{dm}^{-3}$ of $\mathrm{Ca}, \mathrm{Mg}, \mathrm{K}$ and $\mathrm{H}+\mathrm{Al}$, respectively; and $67 \%$ soil base saturation. Liming was not performed because the percentage of saturation by soil bases was higher than recommended for the cultivation of sweet corn $(\geq 60 \%)$. Also, according to the granulometric analysis, the soil had 592, 161 and $247 \mathrm{~g} \mathrm{~kg}^{-1}$ of clay, silt and sand, respectively.

The experiment was installed in a randomized complete block design, in a $3 \times 5+1$ factorial scheme, with four replications. The treatments corresponded to three doses of molybdenum $(150,300$ and $\left.450 \mathrm{~g} \mathrm{ha}^{-1}\right)$ and five application timings $\left(\mathrm{E}_{1}: 100 \%\right.$ at 15 days after emergence - DDE; $\mathrm{E}_{2}: 100 \%$ at 30 DDE; $\mathrm{E}_{3}: 100 \%$ at $45 \mathrm{DDE} ; \mathrm{E}_{4}: 50 \%$ at 15 and $30 \mathrm{DDE}$ and $\mathrm{E}_{5}: 33.3 \%$ at 15,30 and $\left.45 \mathrm{DDE}\right)$. The control treatment $(\mathrm{C})$ corresponded to the non-application of molybdenum.

The experimental unit consisted of five rows of plan$\mathrm{ts}, 7.5 \mathrm{~m}$ long. The variables were evaluated in the plants located in the central five meters of the three central rows of each experimental unit.

The sweet corn 'SVN 9298', from Monsanto, was sown on August 24, 2015, with $0.50 \mathrm{~m}$ between rows. After $7 \mathrm{DDE}$, clearing was done in order to adjust the distance between plants to $0.33 \mathrm{~m}$, which allowed an estimated population of 60,606 plants/ha.
Based on the recommendation of Cantarella et al. (1997), $60 \mathrm{~kg} \mathrm{ha}^{-1}$ of $\mathrm{P}_{2} \mathrm{O}_{5}$ (simple superphosphate) and $50 \mathrm{~kg} \mathrm{ha}^{-1}$ of $\mathrm{K}_{2} \mathrm{O}$ (potassium chloride) were applied at planting. In coverage, $40 \mathrm{~kg} \mathrm{ha}^{-1} \mathrm{~K}_{2} \mathrm{O}$ were applied only once, in stage $\mathrm{V}_{4}$. In the case of $\mathrm{N}$ (urea), $170 \mathrm{~kg}$ $\mathrm{ha}^{-1}$ were applied, fractionated three times in equal amounts (at $3 \mathrm{DDE}$; at $20 \mathrm{~d}$ after the first application, which coincided with the beginning of the definition of the productive potential, in stage $\mathrm{V}_{4}$; and $20 \mathrm{~d}$ after the second application, when the number of rows of grain was defined in the ear, in stage $V_{6}$ ).

Ammonium molybdate was used as the source of Mo, via foliar spraying. Tween ${ }^{\circledR}$ adhesive dispersant was used, at $10 \mathrm{~mL}$ per $100 \mathrm{~L}$ of water. The volumes of the solution (ammonium molybdate plus dispersant) in the foliar applications at 15, 30 and $45 \mathrm{DDE}$ were 270, 400 and $600 \mathrm{~L} \mathrm{ha}^{-1}$, respectively.

The evaluated characteristics were: nitrogen content $\left(\mathrm{g} \mathrm{kg}^{-1}\right)$ and molybdenum (mg kg-1) in the diagnostic leaf, total number of ears (ears/ha), number of commercial ears (commercial ears/ha), total ear productivity $\left(\mathrm{kg} \mathrm{ha}^{-1}\right)$, commercial ear productivity $\left(\mathrm{kg} \mathrm{ha}^{-1}\right)$, ear length $(\mathrm{cm})$, ear diameter $(\mathrm{cm})$ and grain productivity $\left(\mathrm{kg} \mathrm{ha}^{-1}\right)$.

The data were subjected to analysis of variance (FTest), and, when there was a significant effect, regression analysis was performed for the Mo doses and the Tukey test (5\%) was used for the Mo application timing, using AgroEstat (Barbosa and Maldonado Junior, 2015).

\section{RESULTS AND DISCUSSION}

There was an effect from the interaction of the evaluated factors on the Mo concentration in the sweet corn leaves (Tab. 1). Adjustments were only obtained for Mo concentrations when the application was made at $45 \mathrm{DDE}\left(\mathrm{E}_{3}\right)$ and when it was fractionated at 15, 30 and $45 \mathrm{DDE}\left(\mathrm{E}_{5}\right)$ (Fig. 1).

In the splitting of the factor interactions, it was verified that, in $\mathrm{E}_{3}$, the minimum concentration of foliar Mo $\left(3.0 \mathrm{mg} \mathrm{kg}^{-1}\right)$ was obtained with the dose of $240 \mathrm{~g} \mathrm{ha}^{-1}$. However, with the increase in Mo doses, there was an increase in the micronutrient content, reaching a maximum of $6.6 \mathrm{mg} \mathrm{kg}^{-1}$ with the highest Mo dose. In $\mathrm{E}_{5}$, the lowest $\left(2.85 \mathrm{mg} \mathrm{kg}^{-1}\right)$ and highest (4.0 $\mathrm{mg} \mathrm{kg}^{-1}$ ) concentration of foliar Mo was obtained with 150 and $450 \mathrm{~g} \mathrm{ha}^{-1}$ of Mo, respectively (Fig. 1). 


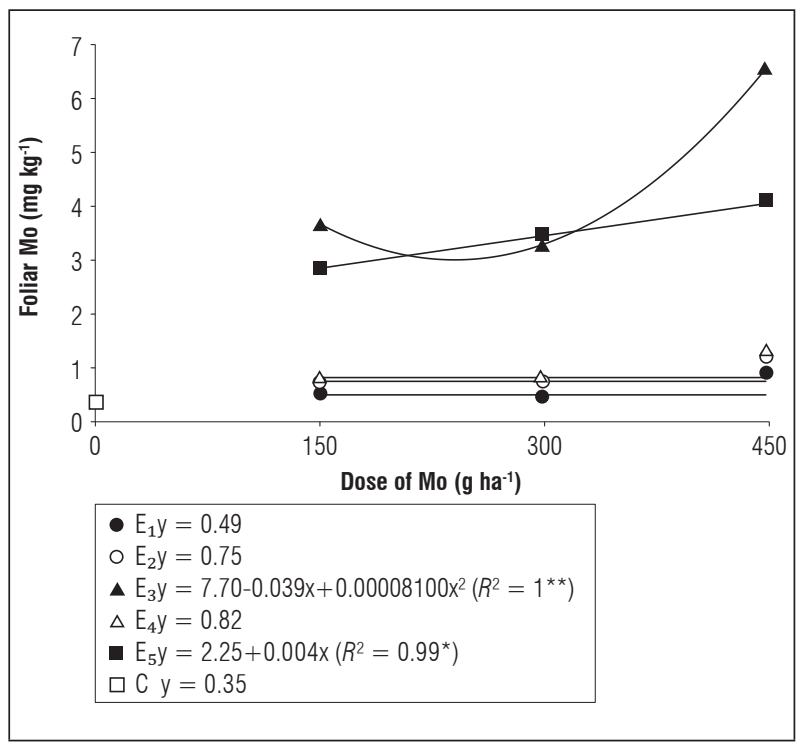

Figure 1. Foliar concentration of Mo as a function of doses and timing of Mo foliar applications in sweet corn 'SVN9298' (C = control, without application of Mo).

The highest concentration of Mo in $\mathrm{E}_{3}$ can be attributed to the greater foliar area that the corn plants had between the evaluated periods, according to the observation made by Kraemer et al. (2009), who found a greater foliar absorption of nutrients when plants had a greater foliar area. Also, the fact that the spraying in $\mathrm{E}_{3}$ was done without dose fractioning may have contributed to the improvement of the efficiency of foliar fertilization.

Plants not fertilized with Mo had $0.35 \mathrm{mg} \mathrm{kg}^{-1}$ of Mo, differing from the average content $\left(2 \mathrm{mg} \mathrm{kg}^{-1}\right)$ observed in the plants that received this element via foliar spraying (Tab. 1).

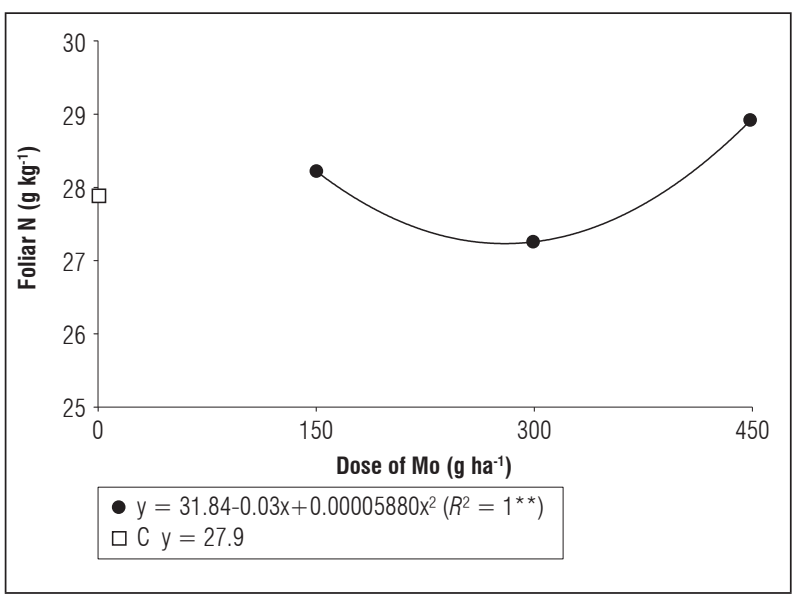

Figure 2. Foliar concentration of $\mathbf{N}$ and control treatment (C) as a function of the Mo foliar application in sweet corn 'SVN 9298'.

Although the levels of molybdenum in the soil were not determined, the foliar analysis on the diagnostic leaf allowed for a correcting follow-up foliar fertilization with Mo. The foliar levels of Mo estimated in the fertilized and unfertilized plants were above the critical level considered suitable for this crop, which is 0.1 to $0.2 \mathrm{mg} \mathrm{kg}^{-1}$, according to Cantarella et al. (1997).

Despite the divergence in the results of the foliar application of Mo on the foliar concentration of Mo, positive in corn used for grain (Araújo et al., 2010; Caioni, 2015) and popcorn (Teixeira, 2006) and negative in conventional corn (Teixeira, 2006; Pereira, 2010). Bodi et al. (2015), Kovács et al. (2015) and Taiz and Zeiger (2009) highlighted the importance of providing this micronutrient for increasing its concentration in corn because of its role in $\mathrm{N}$ metabolism,

Table 1. F valor for analysis of variance of molybdenum (CMo) and nitrogen (CN) foliar concentrations, total number of ears (NTE), number of commercial ears (NEC), ear length (COM), ear diameter (DIAM), total productivity of ears with husk (PTEP), commercial productivity of ears without husk (PECSP) and grain productivity (PG) of sweet corn 'SVN 9298', as a function of the doses and timing of Mo foliar applications.

\begin{tabular}{|l|c|c|c|c|c|c|c|c|c|}
\hline \multicolumn{1}{|c|}{ Sources of variation } & CMo & CN & NTE & NEC & COM & DIAM & PTEP & PECSP & PG \\
\hline Doses of molybdenum (D) & $16.95^{* *}$ & $4.17^{*}$ & $<0.00^{\text {NS }}$ & $14.52^{* *}$ & $0.96^{\text {NS }}$ & $0.36^{\text {NS }}$ & $2.23^{\text {NS }}$ & $2.89^{\text {NS }}$ & $3.08^{\text {NS }}$ \\
\hline Application timing (E) & $90.24^{* *}$ & $1.27^{\text {NS }}$ & $0.28^{\text {NS }}$ & $2.53^{\text {NS }}$ & $0.79^{\text {NS }}$ & $1.53^{\text {NS }}$ & $1.87^{\text {NS }}$ & $1.77^{\text {NS }}$ & $0.68^{\text {NS }}$ \\
\hline $\mathrm{D} \times \mathrm{E}$ & $4.25^{* *}$ & $0.92^{\mathrm{NS}}$ & $0.05^{\mathrm{NS}}$ & $1.98^{\mathrm{NS}}$ & $0.68^{\mathrm{NS}}$ & $1.75^{\mathrm{NS}}$ & $0.91^{\mathrm{NS}}$ & $0.95^{\mathrm{NS}}$ & $1.72^{\mathrm{NS}}$ \\
\hline$(\mathrm{D} \times \mathrm{E}) \times \mathrm{C}$ & $22.65^{* *}$ & $0.08^{\mathrm{NS}}$ & $15.02^{* *}$ & $16.2^{\mathrm{NS}}$ & $6.81^{*}$ & $29.43^{* *}$ & $0.60^{\mathrm{NS}}$ & $2.33^{\mathrm{NS}}$ & $5.47^{*}$ \\
\hline $\mathrm{CV}(\%)$ & 35.21 & 6.53 & 1.40 & 6.25 & 3.37 & 2.33 & 6.57 & 9.54 & 6.58 \\
\hline
\end{tabular}

NS, * and **: non-significant and significant at $5 \%$ and $1 \%$ probability levels by F-test, respectively.

C: control treatment, without application of Mo. 
directly affecting the growth and development of plants.

The effect of Mo doses on the $\mathrm{N}$ content was observed, with a quadratic adjustment of this variable (Fig. 2). The $\mathrm{N}$ concentrations were within the appropriate range for corn (27 to $35 \mathrm{~g} \mathrm{~kg}^{-1}$ ), according to Cantarella et al. (1997).

The $\mathrm{N}$ content in the diagnostic leaf for the nutritional status of sweet corn sprayed with Mo (28.1 $\mathrm{g} \mathrm{kg}^{-1}$ ) was similar to that obtained in the control plants, which did not receive the micronutrient (27.9 $\mathrm{g} \mathrm{kg}^{-1}$ ).

It was verified that the lowest concentration of $\mathrm{N}$ $\left(27.2 \mathrm{~g} \mathrm{~kg}^{-1}\right)$ was obtained with $280.35 \mathrm{~g} \mathrm{ha}^{-1}$ of Mo. Starting at this dose, there were increases in the foliar content of $\mathrm{N}$, reaching $29.3 \mathrm{~g} \mathrm{~kg}^{-1}$ with the highest dose of Mo (450 $\mathrm{g} \mathrm{ha}^{-1}$ ) (Fig. 2). According to various authors, the importance of Mo lies in the role it plays in the assimilation of $\mathrm{N}$ since it is a component of the enzyme nitrate reductase, which is responsible for catalyzing the biological reduction of $\mathrm{NO}_{3}{ }^{-}$to $\mathrm{NO}_{2}$ , which is subsequently reduced to $\mathrm{NH}_{4}{ }^{+}$(Hamlin , 2007; Fageria, 2009; Tejada-Jiménez et al., 2013; Kóvacs et al., 2015).

The total number of ears (NTE) was not influenced by the doses, the timing of the foliar applications of Mo, or the interaction of these factors (Tab. 1). Meanwhile, there was a significant difference between the means of the control treatment $(58,503$ ears/ha) and the factorial treatments $(60,191$ ears/ha), with an increase of $2.9 \%$ in the NTE in the sweet corn. According to Araújo et al. (2010), this variable can be altered when some nutritional imbalance occurs, a fact that was not found in this study, either as the result of a deficiency or excess, or even as the result of foliar concentrations of Mo and N. Therefore, the higher NTE resulted from the higher foliar contents of Mo and $\mathrm{N}$, as a consequence of the molybdenum fertilization (Fig. 1 and 2). Although significant, the difference between the NTE of the fertilized and unfertilized plants with Mo was small (1,688 ears/ha). Ferreira et al. (2001) and Teixeira (2006), evaluating different Mo doses in corn used for popcorn and conventional corn, did not observe the effect of micronutrient applications on NTE. According to these authors, the lack of response to molybdenum fertilization was because the soil had a satisfactory amount of Mo or because the Mo concentration in the seeds was adequate (Weir and Hudson, 1966).
The number of commercial ears (NEC) was influenced by the foliar application of Mo doses (Tab. 1); this variable was adjusted to the quadratic equation (Fig. 3). The increase in Mo doses benefited the NEC, obtaining the maximum value $(49,583$ commercial ears/ha) with $316 \mathrm{~g} \mathrm{ha}^{-1}$ of Mo, approximately $10 \%$ higher than the NEC verified in the control treatment, which was 44,803 commercial ears/ha.

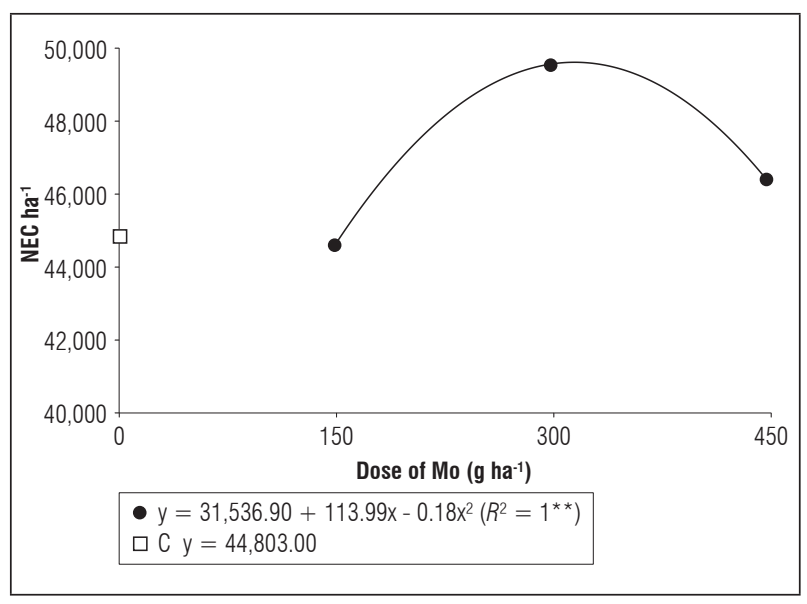

Figure 3. Total number of commercial ears (NEC) and control treatment (C) as a function of the Mo foliar applications in sweet corn 'SVN 9298'.

Molybdenum doses, application timing and the interaction between these factors had no significant effect on the length and diameter of the sweet corn ears. However, there were significant differences between the means of the control treatment and the factorial treatments for these two characteristics (Tab. 1), verifying an increase of $5.3 \%$ in length (from 17.6 to 18.5 $\mathrm{cm}$ ) and $7 \%$ in ear diameter (4.7 to $5.1 \mathrm{~cm}$ ). The values obtained for the length and diameter of the ears were higher than that required for commercial sweet corn (>15 cm in length and $>3 \mathrm{~cm}$ in diameter) (Albuquerque et al., 2008). The results differed from those of Caioni (2015), who found no effect from foliar applications of Mo on these variables. According to various authors, the length and diameter of corn ears are greatly influenced by genotype and depend less on the environment and fertilization (Fernandes et al., 2005; Ohland et al., 2005; Goes et al., 2012).

There was no significant effect of Mo doses, application timing, or the interaction of these factors on the total production of ears with husk (PTEP), the total production of commercial ears without husk (PECSP) or the grain production (PG) (Tab. 1). 
There was adjustment of the increasing linear equation for the PTEP (Fig. 4), obtaining the maximum value $\left(20,942 \mathrm{~kg} \mathrm{ha}^{-1}\right)$ with the dose of $450 \mathrm{~g} \mathrm{ha}^{-1}$ of Mo, via foliar spraying. Productivity similar to the present study was also recorded by Cardoso et al. (2010) and Luz et al. (2015) in green maize 'HTMV1' $\left(21,374 \mathrm{~kg} \mathrm{ha}^{-1}\right)$ and sweet corn 'SWC01' $(21,790 \mathrm{~kg}$ $\left.\mathrm{ha}^{-1}\right)$, respectively. The effect of molybdenum fertilization on PTEP was probably due to the fact that Mo promoted a better use of absorbed $\mathrm{N}$, as verified by various authors (Valentini et al., 2005; Caioni, 2015; Kovács et al., 2015). Because of the multiple functions that it fulfills in the metabolism of plants (acting mainly in the synthesis of proteins and as a component of chlorophyll), $\mathrm{N}$ stimulates growth and development (increasing the green mass index and photosynthetic performance), altering various yield components and positively influencing the productivity of ears and grains (Gaspareto et al., 2014), a fact that was found in this study for the productivity of sweet corn.

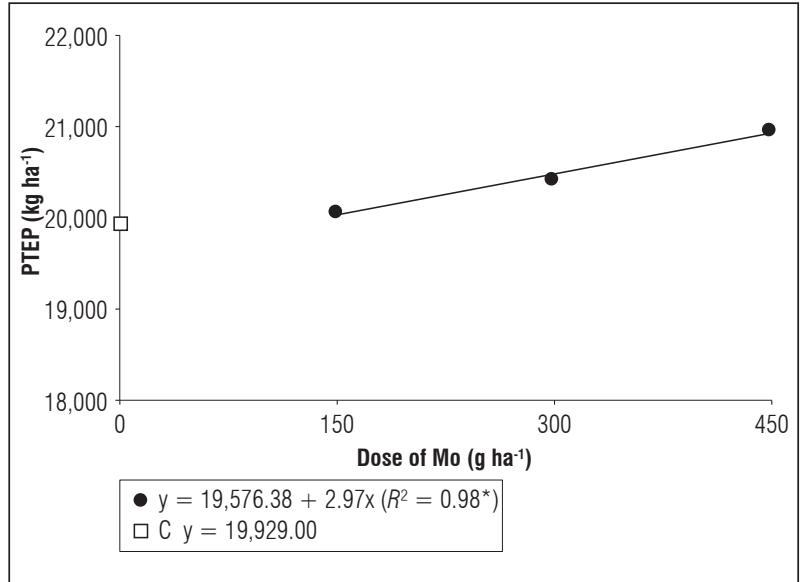

Figure 4. Total productivity of ears with husk (PTEP) and control treatment (C) as a function of the Mo foliar applications in sweet corn 'SVN 9298'.

The productivity of commercial ears without husk (PECSP) was adjusted to the quadratic equation as a function of Mo doses (Fig. 5). With the estimated dose of $311.3 \mathrm{~g} \mathrm{ha}^{-1}$ of Mo, applied via foliar spraying, the highest PECSP $\left(13,211 \mathrm{~kg} \mathrm{ha}^{-1}\right)$ was obtained, lower than that found by Cruz et al. (2015), who verified a productivity of $9,919 \mathrm{~kg} \mathrm{ha}^{-1}$ of PECSP with the hybrid 'GSS 41243' when evaluating different $\mathrm{N}$ doses.

As stated for the PECSP, grain productivity (PG) was adjusted to the quadratic model (Fig. 6). The highest

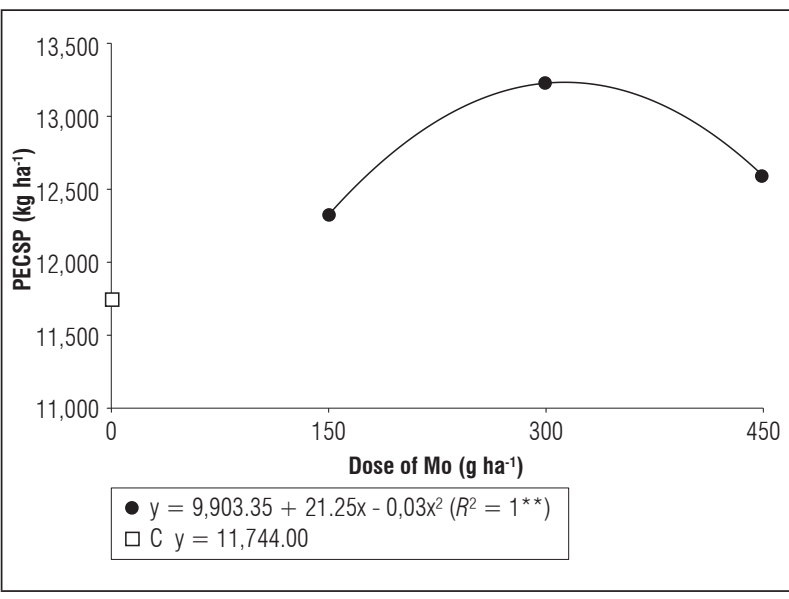

Figure 5. Productivity of commercial ears without husk (PECSP) and control treatment (C) as a function of the Mo foliar applications in sweet corn 'SVN 9298'.

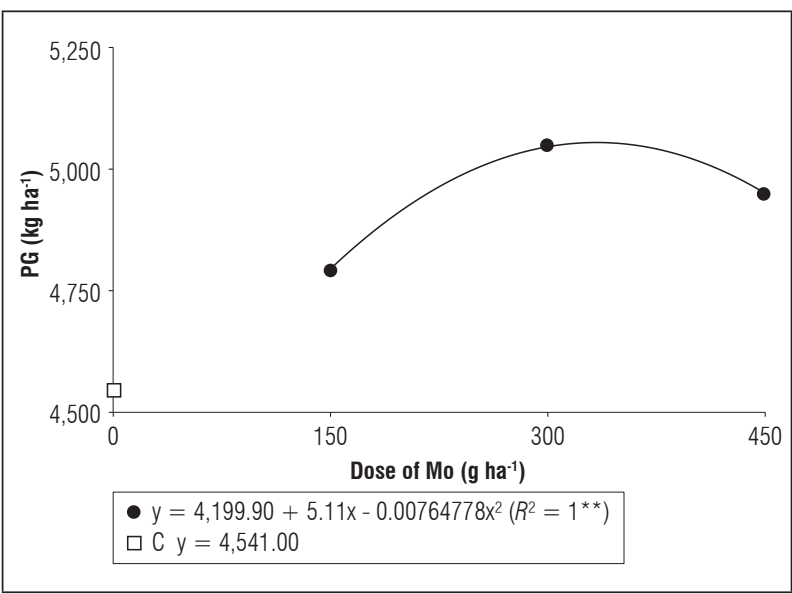

Figure 6. Grain productivity (PG) and control treatment (C) as a function of the Mo foliar applications in sweet corn 'SVN 9298'.

PG $\left(5,055 \mathrm{~kg} \mathrm{ha}^{-1}\right)$ was obtained with a dose of 334.4 $\mathrm{g} \mathrm{ha}{ }^{-1}$ of Mo, via foliar spraying, with an increase of $8.6 \%$ in relation to the control treatment $(4,541 \mathrm{~kg}$ $\left.\mathrm{ha}^{-1}\right)$. The same positive effect of the foliar Mo applications was observed by Caioni (2015), reaching a productivity of $9,028 \mathrm{~kg} \mathrm{ha}^{-1}$ of grains. Araújo et al. (2010) obtained productivity of $4,251 \mathrm{~kg} \mathrm{ha}^{-1}$ of grains in corn used for popcorn, with doses of up to $1,600 \mathrm{~g}$ $\mathrm{ha}^{-1}$ of Mo. An increase in PG was also noted by Valentini et al. (2005) in conventional corn. The maximum PG, close to that observed in this study, was verified by Pereira et al. (1999) with the application of $111 \mathrm{~g} \mathrm{ha}^{-1}$ of foliar Mo. The authors obtained a $6.7 \%$ 
increase in PG in relation to treatments without the application of micronutrients. On the other hand, Silva et al. (2018) did not verify the effect of different doses of Mo $\left(0,25,105,210,315\right.$ and $\left.420 \mathrm{~g} \mathrm{ha}^{-1}\right)$ on grain productivity because the Mo concentrations in the soil and in the seed were sufficient to meet the demand of the corn plants.

Positive results for foliar Mo applications on grain productivity in conventional corn were verified by Santos et al. (2010) and Heidarzade et al. (2016). Caioni et al. (2017) observed effects of nitrogen and molybdenum fertilization on the productivity of grains in corn, with increases in productivity as Mo doses increased, concluding that this effect was probably due to the greater accumulation of proteins in grains as a result of the greater availability of $\mathrm{N}$ in the soil solution. According to Araújo et al. (2010), the addition of Mo, via foliar spraying, can increase the activity of the enzyme nitrate reductase, which participates directly in the metabolism of $\mathrm{N}$. In addition, $\mathrm{N}$ acts on pollen formation and on the reduction of abortion of ovules, consequently affecting grain formation and crop productivity (Carvalho and Nakagawa, 2000).

No toxicity symptoms were observed when the highest Mo dose was applied, indicating that the sweetcorn hybrid 'SVN 9298' can tolerate high doses of this micronutrient without impairing grain productivity. Teixeira (2006), applying different doses of Mo (between 0 to $1600 \mathrm{~g} \mathrm{ha}^{-1}$ ) via foliar spraying, did not observe symptoms of toxicity in corn plants, concluding that this crop has a high response capacity at high doses of this micronutrient. Vieira et al. (2005), evaluating high Mo doses (between 0 and $1440 \mathrm{~g}$ ha $\left.{ }^{1}\right)$ via foliar spraying in a bean crop, verified that the application of high doses of this micronutrient did not present a toxic effect for the crop. According to some authors, the use of high doses of molybdenum should promote the accumulation of this nutrient in toxic amounts in plants; however, this does not occur because plants, in general, have reasonable tolerance to the excessive accumulation of this micronutrient (Leite et al., 2007).

\section{CONCLUSIONS}

Under the conditions of this experiment, the application timing and the molybdenum doses influenced the foliar concentration of the micronutrient in sweet corn 'SVN 9298'.
Independent of the application timing, the molybdenum foliar spraying influenced the concentration of nitrogen and the agronomic performance of sweet corn 'SVN 9298'.

The total number of commercial ears, the highest total productivity of ears with husk, the highest productivity of commercial ears without husk and the higher grain productivity of sweet corn 'SVN 9298' were obtained with 316; 450; 311 and $334 \mathrm{~g} \mathrm{ha}^{-1}$ of molybdenum, via foliar spraying, respectively.

Conflict of interests: The manuscript was prepared and reviewed with the participation of the authors, who declare that there exists no conflict of interest that puts at risk the validity of the presented results.

\section{BIBLIOGRAPHIC REFERENCES}

Agarwala, S.C., C. Chatterjee, P.N. Sharma, C.P. Sharma, and N. Nautiyal. 1979. Pollen development in maize plants subjected to molybdenum deficiency. Can. J. Bot. 57(18), 1946-1950. Doi: 10.1139/b79-244

Albuquerque, C.J.B., R.G.V. Pinho, I.D. Borges, A.X. de Souza Filho, and I.V.A. Fiorini. 2008. Desempenho de híbridos experimentais e comerciais de milho para produçao de milho verde. Ciênc. Agrotec. 32(3), 768-775. Doi: 10.1590/S1413-70542008000300010

Araújo, G.A. de A., A.R. Teixeira, G.V. Miranda, J.C.C Galvão, and P.R.R. Rocha. 2010. Produtividade e qualidade fisiológica de sementes de milho-pipoca submetido à aplicação foliar de molibdênio. Sci. Agrar. 11(3), 231237. Doi: 10.5380/rsa.v11i3.17509

Barbosa, J.C. and W. Maldonado Junior. 2015. AgroEstat sistema para análises estatísticas de ensaios agronômicos. FCAV/UNESP, Jaboticabal, Brazil.

Bodi, E., S.Z. Veres, F. Garousi, S.Z. Varallyay, and B. Kovacs. 2015. Effects of molybdenum treatments on maize and sunflower seedlings. Int. J. Biol. Food Veter. Agric. Eng. 9(5), 375-378.

Caioni, S. 2015. Doses de molibdênio e nitrogênio em milho safrinha e efeito residual na cultura da soja em plantio direto. MSc thesis. Universidade Estadual Paulista, Ilha Solteira, Brazil.

Caioni, S., E. Lazarini, T. de L. Parente, J.W. Bossolani, L. G.M. de Souza, R.S. Pivetta, and L. Dickmann. 2017. Efeito residual da adubação nitrogenada e molibídica no milho sobre a soja cultivada em sucessão. Rev. Espacios 38(19), 4.

Cantarella, H., B. van Raij, and C.D.E. Camargo. 1997. Cereais. pp. 45-71. In: Raij, B. van, H. Cantarella, J.A. Quaggio, and A.M.C. Furlani (eds.). Recomendações de adubação e calagem para o Estado de São Paulo. IAC, Campinas, Brazil. 
Cardoso, M.J., A.R. Silva, L.J.M. Guimarães, S.N. Parentoni, and J.W. Setubal. 2010. Produtividade de espiga verde de milho sob diferentes níveis de nitrogênio. Hortic. Bras. 28(2) (Supl. CD), 3786-3789.

Carvalho, N.M. and J. Nakagawa. 2000. Sementes: ciência, tecnologia e produção. FUNEP, Jaboticabal, Brazil.

Cruz, C.A., A.B. Cecílio Filho, N.B. Meneses, T.P.L. Cunha, R.H.D. Nowaki, and J.C. Barbosa. 2015. Influence of amount and parceling of nitrogen fertilizer on productivity and industrial revenue of sweet corn (Zea mays L.). Aust. J. Crop Sci. 9(10), 895-900.

EMBRAPA, Empresa Brasileira de Pesquisa Agropecuária. 2006. Sistema brasileiro de classificação de solos. Embrapa Solos, Rio de Janeiro, Brazil.

Fageria, N.K. 2009. The use of nutrients in crop plants. CRC Press, Taylor \& Francis Group, Boca Raton, FL.

Fernandes, F.C.S., S.B.O. Arf, and J.A. da C. Andrade. 2005. Doses, eficiência e uso de nitrogênio por seis cultivares de milho. Rev. Bras. Milho Sorgo 4(2), 195-204. Doi: 10.18512/1980-6477/rbms.v4n2p195-204

Ferreira, A.C. de B., G.A. de A. Araújo, P.R.G. Pereira, and A.A. Cardoso. 2001. Características agronômicas e nutricionais do milho adubado com nitrogênio, molibdênio e zinco. Sci. Agric. 58(1), 131-138. Doi: 10.1590/ S0103-90162001000100020

Gaspareto, D., A.A. Ribon, V.T.L. Hermógenes, and K.L. Fernandes. 2014. Efeito de doses de nitrogênio e molibdênio na produtividade do milho híbrido em Campo Grande-MS. Campo Digital 9(2), 37-48.

Goes, R.J., R.A.F. Rodrigues, O. Arf, and R.G. Vilela. 2012. Nitrogênio em cobertura para o milho (Zea mays L.) em sistema plantio direto na safrinha. Rev. Bras. Milho Sorgo 11(2), 169-177. Doi: 10.18512/1980-6477/ rbms.v11n2p169-177

Hamlin, R.L. 2007. Molybdenum. pp. 375-394. In: Barker, A.V. and D.J. Pilbeam (eds.). Handbook of plant nutrition. CRC Press; Taylor and Francis Group, Boca Raton, FL.

Heidarzade, A., M. Esmaeli, M. Bahmanyar, R. Abbasi, and M. Karimi. 2016. The effect of iron and molybdenum spray on mayze (S.C. 704 cultivar) under different water status conditions. Inter. J. Agri. Biosci. 5(2), 54-59.

Kovács, B., A. Puskás-Preszner, L. Huzsvai, L. Lévai, and E. Bódi. 2015. Effect of molybdenum treatment on molybdenum concentration and nitrate reduction in maize seedlings. Plant Physiol. Biochem. 96, 38-44. Doi: 10.1016/j.plaphy.2015.07.013

Kraemer, T., M. Hunsche, and G. Noga. 2009. Cuticular calcium penetration is directly related to the area covered by calcium within droplet spread area. Sci. Hortic. 120(2), 201-206. Doi: 10.1016/j.scienta.2008.10.015

Leite, U.T., G.A. de A. Araújo, G.V. Miranda, R.F. Vieira, J.E. de S. Carneiro, and A.A. Pires. 2007. Rendimento de grãos e componentes de rendimento do feijoeiro em função da aplicação foliar de doses crescentes de molibdênio. Acta Sci. Agron. 29(1), 113-120. Doi: 10.4025/ actasciagron.v29i1.74

Luz, J.M.Q., J.S. Camilo, V.H.B. Barbieri, R.M. Rangel, and R.C. Oliveira. 2014. Produtividade de genótipos de milho doce e milho verde em função de intervalos de colheita. Hortic. Bras. 32(2), 163-167. Doi: 10.1590/ S0102-05362014000200007

Maynard, D.N. and G.J. Hochmuth. 2007. Knott's handbook for vegetable growers. $5^{\text {th }}$ ed. John Wiley \& Sons, Inc., Hoboken, NJ. Doi: 10.1002/9780470121474

Mendoza-Cortez, J.W., A.B. Cecílio Filho, and N.B. Meneses. 2016. Nutrição e adubação da cultura do milhodoce. pp. 475-505. In: Prado, R.M. and A.B. Cecílio Filho (eds.). Nutrição e adubação de hortaliças. FCAV/ CAPES, Jaboticabal, Brazil.

Ohland, R.A.A., L.C.F. Souza, L.C. Hernani, M.E. Marchetti, and M.C. Gonçalves. 2005. Culturas de cobertura do solo e adubação nitrogenada no milho em plantio direto. Ciênc. Agrotec. 29(3), 538-544. Doi: 10.1590/ S1413-70542005000300005

Pereira, F.R.S. 2010. Doses e formas de aplicação de molibdênio na cultura do milho. $\mathrm{PhD}$ thesis. Universidade Estadual Paulista, Botucatu, Brazil.

Pereira, S.L., G.A.A. Araújo, C.S. Sediyama, C. Viera, and P.R. Mosquim. 1999. Efeitos da adubação nitrogenada e molibdica sobre a cultura do milho. Ciênc. Agrotec. 23(4), 790-798.

Santos, M.M., R.R. Fidelis, F.L. Finger, G.V. Miranda, I.R. Silva, and J.C.C. Galvão. 2012. Atividade enzimática na cultura do milho (Zea mays L.) em função do molibdênio e de épocas de adubação nitrogenada. Rev. Bras. Milho Sorgo 11(2), 145-155. Doi: 10.18512/19806477/rbms.v11n2p145-155

Santos, M.M., J.C.C. Galvão, I.R. Silva, G.V. Miranda, and F.L. Finger. 2010. Épocas de aplicação de nitrogênio em cobertura na cultura do milho em plantio direto, e alocação do nitrogênio $\left({ }^{15} \mathrm{~N}\right)$ na planta. Rev. Bras. Ciênc. Solo 34(4), 1185-1194. Doi: 10.1590/ S0100-06832010000400018

Silva, C.G.M., S.G. Moreira, R.M. Lupp, G.F. Castro, B.H.A. Rehagro, and A.A.P. Silva. 2018. Doses de molibdênio na produtividade do milho. Rev. Agroambiental 10(1), 47-55. Doi: 10.18406/2316-1817v10n120181067

Taiz, L. and E. Zeiger. 2009. Fisiologia vegetal. $4^{\text {th }}$ ed. Artmed, Porto Alegre, Brazil.

Tanner, P.D. 1978. A relationship between premature sprouting on the cob and the molybdenum and nitrogen status of maize grain. Plant Soil 49(2), 427-432. Doi: 10.1007/BF02149751

Teixeira, A.R. 2006. Doses de molibdênio nas culturas do milho comum e milho-pipoca. MSc thesis. Universidade Federal de Viçosa, Viçosa, Brazil. 
Tejada-Jiménez, M., A. Chamizo-Ampudia, A. Galván, E. Fernández, and A. Llamas. 2013. Molybdenum metabolism in plants. Metallomics 9, 1191-1203. Doi: $10.1039 / \mathrm{c} 3 \mathrm{mt} 00078 \mathrm{~h}$

Valentini, L., F.C. Coelho, and M. dos S. Ferreira. 2005. Teor de nitrogênio foliar e produtividade de três cultivares de milho (Zea mays L.) submetido as adubações nitrogenada e molíbdica. Rev. Ceres 52(302), 567-577.
Vieira, F.V., L.T. Salgado, and A.C. de B. Ferreira. 2005. Performance of common bean using seeds harvested from plants fertilized with high rates of molybdenum. J. Plant Nutr. 28(2), 363-377. Doi: 10.1081/ PLN-200047631

Weir, R.G. and A. Hudson. 1966. Molybdenum deficiency in maize in relation to seed reserves. Aust. J. Exp. Agric. Anim. Husb. 6(20), 35-41. Doi: 10.1071/EA9660035 